\title{
A Note on the Natural Relocation of Marchalina hellenica (Gennadius) from Pine to Fir Trees
}

\author{
A. E. Tsagkarakis*, N. G. Emmanouel \\ Laboratory of Agricultural Zoology and Entomology, Agricultural University of Athens, Athens, Greece \\ Email: *atsagarakis@aua.gr
}

Received 28 June 2016; accepted 15 July 2016; published 18 July 2016

Copyright (C) 2016 by authors and Scientific Research Publishing Inc.

This work is licensed under the Creative Commons Attribution International License (CC BY).

http://creativecommons.org/licenses/by/4.0/

c) (i) Open Access

\begin{abstract}
Marchalina hellenica (Gennadius) (Hemiptera: Margarodidae) is the most important honeydew producing insect in Greece. It was referred as monophagus, feeding exclusively on pine trees, until 1995 when it was successfully established on fir trees after artificial "inoculation" at Menalo and Helmos mountains. In this scientific note, the first record of natural relocation of $M$. hellenica from pine to fir trees is referred.
\end{abstract}

\section{Keywords}

\section{Marchalina hellenica, Honeydew, Relocation, Abies cephalonica, Parnis, Oiti, Greece}

\section{Introduction}

Marchalina hellenica (Gennadius) (Hemiptera: Margarodidae) is the most significant honeydew producing insect in Greece and neighboring countries (mainly in Turkey). Due to the installation and its feeding in the trunk and the branches of pine trees, excretion of honeydew is caused, which the bee collects, processes and converts to honey.

Other important to apiculture insects like Physokermes hemicryphus (Dalman), Eulecanium sericeum (Lindiger), Mindarus abietinus (Koch), Cinara spp. are present on fir trees, especially on Abies cephalonica Loudon. Honey from fir trees constitutes the $5 \%-10 \%$ of the annual honey production of Greece, contrary to that from pine, which reaches $60 \%$ - 65\% [1]-[5].

Marchalina hellenica was considered a monophagus species, feeding exclusively on Pinus, particularly $P$. brutia Tenore, P. halepensis Miller, P. sylvestris L. and P. nigra (Arnold). However, Bacandritsos [2] [6] and

*Corresponding author. 
Bacandritsos et al. [7] reported that artificial inoculations of M. hellenica on A. cephalonica were realized at the regions of Menalo and Helmos mountains, during 1995-1995, and their result was the first verified establishment on the trees in 1997. On the contrary, the artificial inoculation at Fteri Mountain during 1993 and 1994 was not successful, which was believed to be due to the presence of pine trees in the region of inoculation at Fteri and their absence at Menalo and Helmos [2]. Since then, no other reference about the establishment, natural or artificial of $M$. hellenica on fir tree has been reported.

This scientific note is about the observation of $M$. hellenica on fir trees neighboring with pine trees in two different forestry environments in Greece. The first observation was made in a region near Panas' Cave at Parnis Mountain, Attiki, and the second at Oiti Mountain, Phthiotida, close to the mountain refuge. At those places, numerous fir trees had $M$. hellenica individuals installed on the trunk and the branches (Figures 1-4). In the same

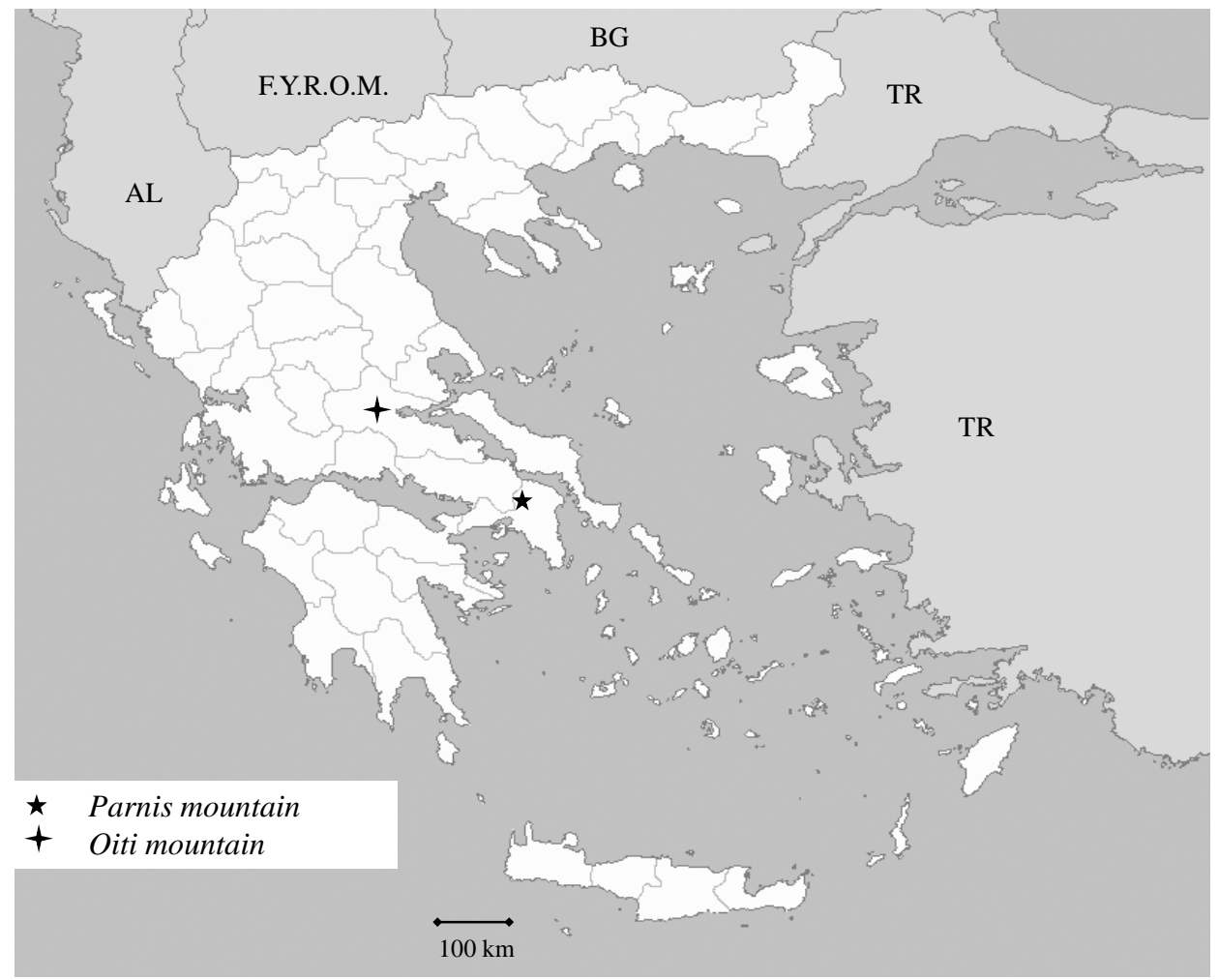

Figure 1. Map of Greece.

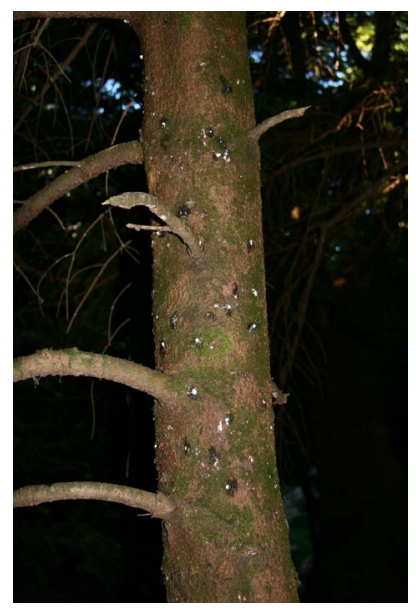

Figure 2. Fir trunk with cotton-like excrements produced by $M$. hellenica. 


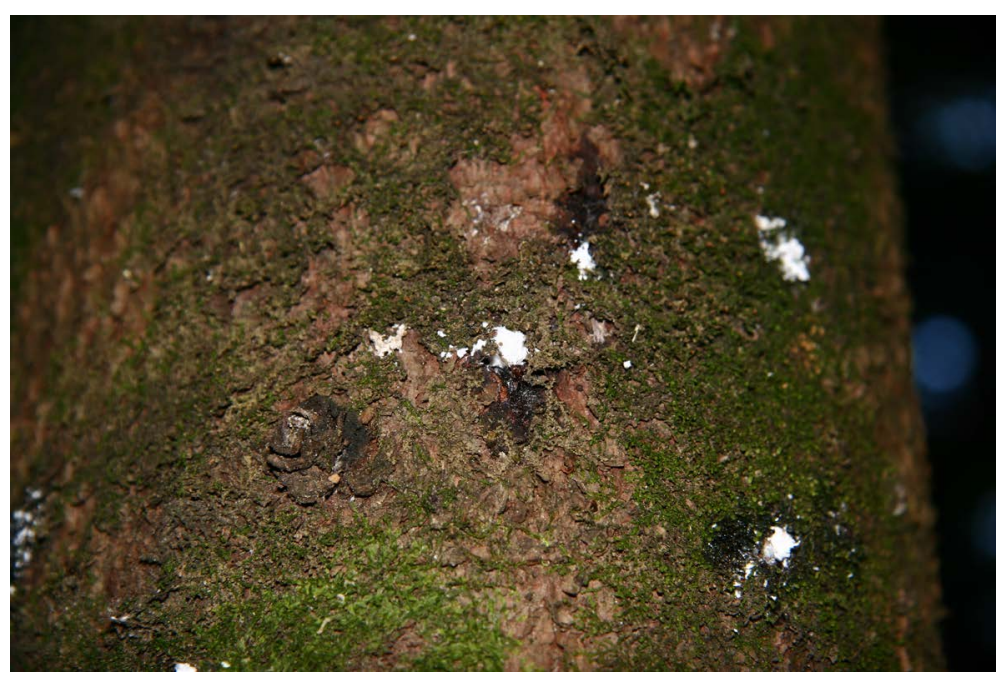

Figures 3. Close up to cotton cushion excrement in the cracks of the bark of fir trees.

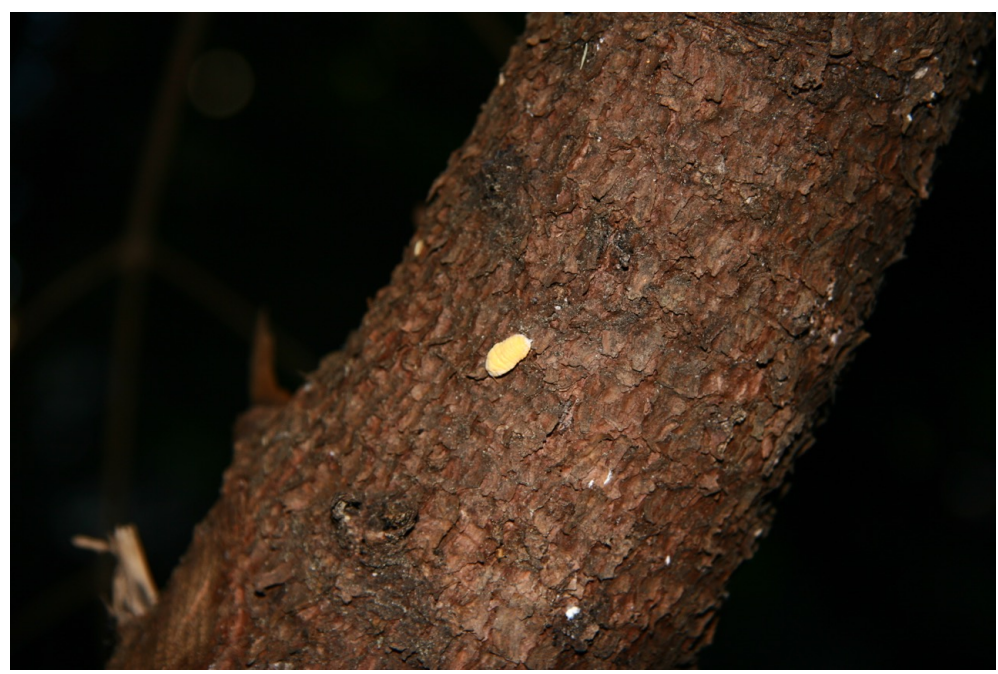

Figure 4. Female adult of M. hellenica on fir tree trunk.

areas, highly infested pine trees ( $P$. halepensis) were also observed. It is remarkable that this is the first time that $M$. hellenica is observed in Attiki and Central Greece on fir trees. It had also to be mentioned that, after a devastating forest fire at Parnis Mountain, most of the fir trees in the aforementioned area were burned.

The total picture (ovipositing females and cotton cushion excrements in cracks of the bark of trunk and main twigs) showed that $M$. hellenica had been installed on those trees. The distance of the areas from the daily human activity and the neighborhood with the infested pine trees results in the hypothesis of the natural transmission of the insects from nearby pine trees to the fir trees. The observation of the present note did not agree with the hypothesis of Bacandritsos [2], who claimed that a possible reason for the unsuccessful inoculation of $M$. hellenica in fir trees at Fteri was the presence of pine trees in the region of inoculation.

Further study on the installation of M. hellenica on fir in other regions of Greece and neighboring countries, as well as the perspectives of the present observation regarding honey production is needed.

\section{References}

[1] Bacandritsos, N. (1998) Control of Mite Diseases of Honey Bees without Use of Pesticides. PhD Thesis, Agricultural University of Athens, Greece.

[2] Bacandritsos, N. (2002) A Scientific Note on the First Successful Establishment of the Monophlebine Coccid Marcha- 
lina hellenica (Coccoidea: Margarodidae) on the Fir Tree (Abies cephalonica). Apidologie, 33, 353-354. http://dx.doi.org/10.1051/apido:2002012

[3] Bacandritsos, N. and Papadopoulou, P. (1999) Physiochemical Characteristics of Honey from Greekpinus Trees. Chemica Chronica, 62, 272-275. (In Greek)

[4] Santas, L.A. (1983) Insects Producing Honeydew Exploited By Bees in Greece. Apidologie, 14, 93-103. http://dx.doi.org/10.1051/apido:19830204

[5] Thrasyvoulou, A. and Manikis, I. (1995) Some Physiochemical and Microscopic Characteristics of Greek Unifloral Honeys. Apidologie, 26, 441-452. http://dx.doi.org/10.1051/apido:19950601

[6] Bacandritsos, N. (2004) Establishment and Honeydew Production of Marchalina hellenica (Coccoidea: Margarodidae) on Fir Tree (Abies cephalonica). Bulletin of Insectology, 57, 127-130.

[7] Bacandritsos, N., Saitanis, K. and Papanastasiou, I. (2004) Morphology and Life Cycle of Marchalina hellenica (Gennadius) (Hemiptera: Margarodidae) on Pine Trees (Parnis Mt.) and Fir (Helmos Mt.) Forests of Greece. Annales de la Societe Entomologique de France (n.s.), 40, 169-176.

\section{Submit or recommend next manuscript to SCIRP and we will provide best service for you:}

Accepting pre-submission inquiries through Email, Facebook, LinkedIn, Twitter, etc.

A wide selection of journals (inclusive of 9 subjects, more than 200 journals)

Providing 24-hour high-quality service

User-friendly online submission system

Fair and swift peer-review system

Efficient typesetting and proofreading procedure

Display of the result of downloads and visits, as well as the number of cited articles

Maximum dissemination of your research work

Submit your manuscript at: http://papersubmission.scirp.org/ 